\title{
EXAMINATION OF CREEP AND SHRINKAGE BEHAVIOR OF CONCRETES WITH OIL SHALE ASH SUBSTITUTED CEMENTS
}

\author{
S. OYMAEL * \\ Department of Architecture \\ Trakya University \\ 22180 Edirne, Turkey
}

\begin{abstract}
Two types of deformation - creep and shrinkage - occurring in cements and concretes are caused by compression and time. They lead to the loss of compressive strength. In the present study both deformation types were experimentally examined using concrete samples made from ordinary Portland cement OPC 32.5 containing 0; 15 and 30\% oil shale ash (OSA). Tests made during months showed that concretes produced using Portland cement with $15 \%$ OSA shrank less than samples containing no OSA (OPC contr.). This finding agrees with the condition that concrete samples produced using $15 \%$ OSA-added cement are not to display a deformation rate higher than $0.1 \%$ within six months and $0.5 \%$ within three months.
\end{abstract}

\section{Introduction}

Two kinds of time-dependent deformations take place in concrete, one of which is shrinkage and the other is creep. Creep is defined as deformations in concrete increasing with time in the case of constant application of loads. Here the concepts of load and time come into play. Creep is inversely proportional to the compressive strength of concrete. In other words, a fast creep could be regarded as a linear function of loading rate. However, shrinkage is also involved in time-dependent deformations. The gel composition of cement paste and non-free water loss in paste pores have a significant effect for creep to take place. Factors that affect creep and shrinkage in concrete are as follows: 1. Type and fineness of cement, 2. Air humidity, 3. Type, amount, and fineness of additives, 4 . Size and volume of construction element, 5. Resistance and tension level of concrete, 6. Type of aggregate and aggregate gradation.

\footnotetext{
* Corresponding author: e-mail sabitoymael@trakaya.edu.tr
} 
Once cement is mixed with water and its hydration starts, its volume decreases, which manifests itself in the form of shrinkage. In this phenomenon termed as viscosity and occurring only in cement paste, if an aggregate is added in the paste, the concrete assumes a viscoelastic character and thus, shrinkage decreases. A decline in the hydration level and compressive strength could be expected in concretes produced using cements with a Blaine fineness (Blaine surface area) below the standards. Nondurable concretes yield higher creep values. Moisture leads to a decrease in concrete shrinkage. In the case of high shrinkage, flowage (sequential deformation) values are high. An experiment examining this phenomenon revealed that flowage increased with increasing atmospheric temperature. Due to the flowage phenomenon, concrete might lose its compressive strength to a certain extent. Thus, constant tension to which the concrete is subjected should not exceed $70 \%$ of the compressive strength of concrete. What is hazardous here is the fact that fracture takes place long after loading [1].

Drying of concrete occurs in a non-homogeneous manner leading to a strong structural effect; self-equilibrated stresses do arise within the material that induce cracking $[2,3]$. Therefore, cracking process interacts with the creep mechanisms of drying concrete. On the one hand, creep strains tend to relax drying generated self-equilibrated stresses and to attenuate crack propagation. On the other hand, crack occurrence leads to redistribution of the overall stress-state (self-equilibrated stresses and stresses due to an applied mechanical load) which affects creep mechanisms [4].

Shrinkage might occur with time even in a concrete that is not subjected to any load. After a certain period of time, shrinkage strain is observed in an unloaded concrete, while creep strain occurs in a concrete under a constant tensile load. Apart from these, both constant load effect and drying shrinkage effect could be possibly observed in concretes. Basic creep strain occurs exclusively due to constant load effect without any water loss in concretes [5-7].

\section{Scope}

The main aim of the study was to assess the time-dependent deformation ability of concretes with and without compressive load. Samples were produced by adding to $\mathrm{PC}$ the oil shale ash produced by burning shale at $700{ }^{\circ} \mathrm{C}$. Thus, it was aimed to reveal the effects of OSA in cement phase, one of the two major constituents of concretes. The study is a sequel to the previous studies on issues such as the appropriate production temperatures for OSA [8], elasticity moduli in OSA-added concretes [9], and length changes of OSA-added concretes in sulphates [10]. 


\section{Materials and methods}

\section{Material used}

In the study, wet-sieved aggregate from Palu, provided by the laboratories of Elazig Vocational College at Firat University, was used. In the aggregate, $D_{\max }$ was selected to be $1 / 5$ of the smallest block size. The aggregate properties in accordance with ASTM C 33 [11] are shown in Table 1.

Table 1. Aggregate properties

\begin{tabular}{|c|l|c|c|c|c|c|c|}
\hline \multirow{2}{*}{$\begin{array}{c}\text { Grain } \\
\text { group, } \\
\text { mm }\end{array}$} & \multirow{2}{*}{$\begin{array}{c}\text { Density, } \\
\mathrm{g} / \mathrm{cm}^{3}\end{array}$} & $\begin{array}{c}\text { Water } \\
\text { absorption, } \\
\%\end{array}$ & $\begin{array}{c}\text { Existing } \\
\text { humidity, } \\
\%\end{array}$ & \multicolumn{2}{|c|}{$\begin{array}{c}\text { Unit weight, } \\
\mathrm{kg} / \mathrm{m}^{3}\end{array}$} & \multicolumn{2}{|c|}{$\begin{array}{c}\text { Abrasion, \% } \\
\text { (all-in aggregate) }\end{array}$} \\
\cline { 5 - 8 } & & & & Loose & Compact & 100 rev. & 500 rev. \\
\hline $0-8$ & $2.69(2.59)$ & 1.15 & 0.70 & 1650 & 1755 & 6.98 & 18.63 \\
$8-16$ & 2.69 & 1.2 & 0.62 & 1580 & 1720 & - & - \\
$16-19$ & 2.69 & 1.2 & 0.44 & 1455 & 1650 & - & - \\
\hline
\end{tabular}

The ordinary Portland cement (OPC) used was OPC 32.5 obtained from Elazig Cement Factory (Table 2). Oil shale ash (OSA) was produced by burning shale at $700{ }^{\circ} \mathrm{C}$ for 1.5 hour [8]. Chemical compositions of OPC and OSA are given in Table 2.

The admixture was premixed with total amount of water before application, and this OSA was used for preparation of concrete mortars. Concrete mixtures were prepared in accordance with ASTM C 109 [12]. The flow table was applied to get a flow of 105-115 mm, according to ASTM C 109.

Table 2. Chemical composition of OPC and OSA [8, 9]

\begin{tabular}{|c|c|c|c|c|c|}
\hline \multicolumn{2}{|c|}{$\begin{array}{l}\text { Components (\%) and } \\
\text { characteristics }\end{array}$} & $\begin{array}{c}100 \% \text { OSA } \\
\text { (Oil shale ash) }\end{array}$ & $\begin{array}{l}0 \% \text { OSA } \\
\text { Substituted } \\
\text { cement }\end{array}$ & $\begin{array}{l}15 \% \text { OSA } \\
\text { Substituted } \\
\text { cement }\end{array}$ & $\begin{array}{l}30 \% \text { OSA } \\
\text { Substituted } \\
\text { cement }\end{array}$ \\
\hline \multicolumn{2}{|l|}{$\mathrm{CaO}$} & 26.40 & 63.0 & 56.16 & 50.12 \\
\hline \multicolumn{2}{|l|}{$\mathrm{SiO}_{2}$} & 39.12 Limits [13]: & 19.78 & 16.79 & 15.45 \\
\hline \multicolumn{2}{|l|}{$\mathrm{Al}_{2} \mathrm{O}_{3}$} & $7.80 \quad \mathrm{~S}+\mathrm{A}+\mathrm{F} \geq 70 \%$ & 5.60 & 5.44 & 4.9 \\
\hline \multicolumn{2}{|l|}{$\mathrm{Fe}_{2} \mathrm{O}_{3}$} & 4.20 & 3.35 & 3.05 & 3.53 \\
\hline \multicolumn{2}{|l|}{$\mathrm{MgO}$} & $9.26(\mathrm{Lim} . \leq 5 \%)[13]$ & 3.0 & 4.87 & 5.37 \\
\hline \multicolumn{2}{|l|}{$\mathrm{SO}_{3}$} & $5.21(\mathrm{Lim} . \leq 5 \%)[13]$ & 2.59 & 3.04 & 3.39 \\
\hline \multicolumn{2}{|l|}{$\mathrm{Na}_{2} \mathrm{O}+\mathrm{K}_{2} \mathrm{O}$} & - & 0.15 & - & - \\
\hline \multicolumn{2}{|l|}{ Loss of ignition } & $3.82(\mathrm{Lim} . \leq 10 \%)[13]$ & 1.73 & 4.36 & 6.2 \\
\hline & - & $\leq 0.1$ & - & - \\
\hline \multirow{2}{*}{\multicolumn{2}{|c|}{$\begin{array}{l}\text { Blaine surface area, } \mathrm{cm}^{2} / \mathrm{g} \\
\text { Specific gravity, } \mathrm{g} / \mathrm{cm}^{3}\end{array}$}} & 6000 (Lim. 3000) [13] & $3180-3500$ & - & - \\
\hline & & 2.7 & 3.15 & 3.11 & 3.11 \\
\hline \multirow{3}{*}{$\begin{array}{l}\text { Lime activity, } \\
\mathrm{N} / \mathrm{mm}^{2} \text { (days) [12] }\end{array}$} & 2 & 15.3 & - & - & - \\
\hline & 7 & $23.9(13.0)$ & - & - & - \\
\hline & 28 & $29.5(8.1)$ & - & - & - \\
\hline \multirow{2}{*}{$\begin{array}{l}\text { Compression } \\
\text { strength (Flexural } \\
\text { strength), N/mm }{ }^{2} \\
\text { (days) [12] }\end{array}$} & 7 & - & $30.6(5.7)$ & $30.9(5.9)$ & $24.5(4.5)$ \\
\hline & 28 & $10(1.8)$ & $42.6(6.8)$ & $44.4(7.0)$ & $37.8(6.5)$ \\
\hline
\end{tabular}




\section{Curing of specimens}

The specimens were cured in $95 \%$ humidity at $20 \pm 2{ }^{\circ} \mathrm{C}$ in the laboratory for 24 hours, and then put into the water bath for 28 days for standard curing. The samples were kept in the controlled-temperature cabinet at $23 \pm 2{ }^{\circ} \mathrm{C}$ with a relative humidity of $50 \pm 4 \%$ until the experiment ended, in accordance with ASTM C 512 [14].

\section{Test performed}

The flow test of mortars was conducted to determine water content necessary for the desired workability. Flow test of fresh mortar was carried out using a flow table and cone immediately after mixing. The amount of water necessary for each mix was determined using flow table expounded in ASTM C109 [12] for maintaining a constant flow.

\section{Experiments, results and discussion}

In the study,three samples were prepared for creep determination (one for each of 0,15 and 30\%); nine samples for compressive strength determination (three for each of 0,15 and $30 \%$ ); three samples for shrinkage experiments (one for each of 0,15 and 30\%). The mortar mix design of the samples is given in Table 3 .

The amount of creep deformation in concrete can be determined experimentally. In the experiment conducted in an environment of certain temperature and humidity, a constant compressive stress is applied to the concrete sample, and the amount of deformation observed in time under this stress is measured. The standards ASTM C 512, TS 3453 and TS 3454 [14-16] describe the experimental setup and experiment method required to measure the concrete creep deformation under a constant compressive stress. According to these standards, the deformation created by the constant stress applied to samples is measured at the following intervals: 1. Immediately before and after loading, 2. In 2-6 hours following the loading, 3. Every day for one week following the loading, 4 . Every week for one month following the loading, 5. Every month for one year.

\section{Table 3. Mortar mix design [8]}

\begin{tabular}{|c|c|c|c|c|c|c|c|c|c|c|}
\hline \multirow{2}{*}{$\begin{array}{c}\text { Content of } \\
\text { OSA, } \%\end{array}$} & \multicolumn{6}{|c|}{ Mix, $\mathrm{kg} / \mathrm{m}^{3}$} & \multirow[t]{2}{*}{$\mathrm{W} / \mathrm{C}$} & \multirow{2}{*}{$\begin{array}{c}\text { Flow, } \\
\%\end{array}$} & \multirow{2}{*}{\begin{tabular}{|c|} 
\\
$\%$
\end{tabular}} & \multirow[b]{2}{*}{$\begin{array}{c}\text { Fresh } \\
\text { conc. } \\
\text { density, } \\
\mathrm{kg} / \mathrm{m}^{3}\end{array}$} \\
\hline & Cem. & OSA & $\begin{array}{l}\text { Fine agg. } \\
0-8 \mathrm{~mm}\end{array}$ & $\begin{array}{c}\text { Coarse agg } \\
8-16 \mathrm{~mm}\end{array}$ & \begin{tabular}{|c|} 
Coarse \\
agg. \\
$16-19 \mathrm{~mm}$
\end{tabular} & Water* & & & & \\
\hline $\begin{array}{c}0 \\
(100 \% \text { OPC })\end{array}$ & 360 & - & 663 & 807 & 346 & 202 & 0.52 & 115 & 1.2 & 2378 \\
\hline 15 & 306 & 54 & 663 & 807 & 346 & 209 & 0.58 & 114 & 1.3 & 2385 \\
\hline 30 & 252 & 108 & 663 & 807 & 346 & 245 & 0.68 & 116 & 1.5 & 2421 \\
\hline
\end{tabular}

* Net water.

** Air is estimated and included in the fresh concrete weight. 
In the experiments, along with $15 \times 30 \mathrm{~cm}$ cylindrical samples, the experimental set seen in Fig. 1 was used as the compression loading unit. In each of the three experimental setups specially produced, four $\varnothing 24 \mathrm{~mm}$ blons (plain bar) and three steel plates with a thickness of $10 \mathrm{~mm}$ placed over these blons were used. The most important characteristic of the experimental set is that the floor plate is fixed and others could freely move up and down. In the set in question, between the two bottommost steel plates, leaf springs (which are also found in train buffers) were used. The load capacity of these springs, each with a load capacity of ten tonnes, was increased by placing two of them on top of one another. The load carrying capacity of each leaf spring was determined under a press machine. So each leaf spring can carry a load of 12 tonnes. However, this value was accepted as 11.5 tonnes to provide safety. What is important here is that the compression strength of the springs in the experimental set is more the $40 \%$ of that of the concrete sample used in the same experimental set because a strain (load) amounting to $40 \%$ of the compression strength of the concrete sample was loaded on the concrete samples in the press machine. The 28-day compression strength of the concrete specimens in the experiments was planned to be higher than $\mathrm{C} 14$, according to which the concrete mix ratios were determined. C14 concrete is characteristic in that it belongs to the lean concrete grade in TS 206-1 [17].

Strain loading was applied to the cylindrical concrete specimens placed between the steel plates in the creep experimental set by a 200-t laboratory press machine. To measure the unit length change in the specimens, a dial indicator with $0.002 \mathrm{~mm}$ accuracy, independent from the system, was used.

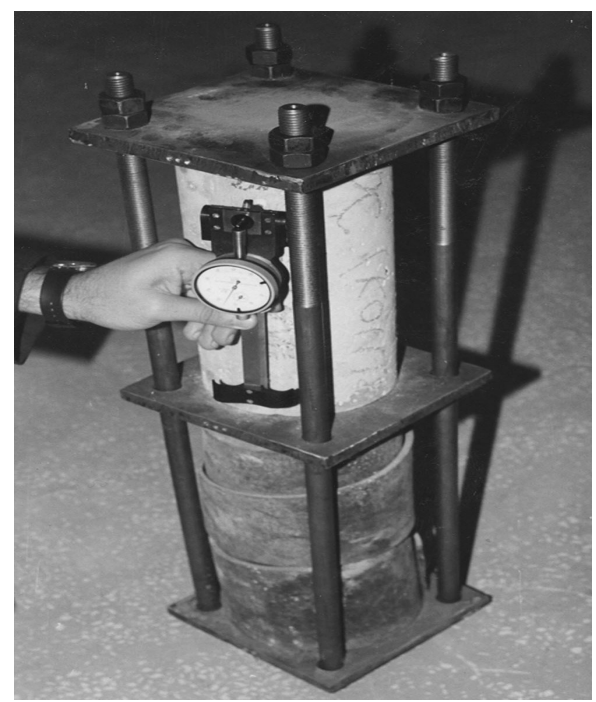

Fig. 1. Measurement of creep deformations in the experimental set in the controlledtemperature cabinet. 
In both creep and shrinkage experiments, length changes were measured using special pins placed in accordance with three measurement directions at equal intervals around the specimen. In order to ensure stability, indents were made in those parts of the brass alloy, stainless pins in the concrete specimen. The pins were placed using cement mortar into the holes made on the three axes of the concrete specimen in accordance with the end intervals of special measuring devices with comparator. The pins were placed in the concrete within the last 3 days when concrete was cured with water. Plastic slugs were placed at the heads of the pins to avoid their deep sinking in the fresh concrete. Following these processes, all specimens were subjected to creep, shrinkage, and compression strength tests.

To provide the basis for the creep experiment, first, compression strengths/tensile strains under press were found using the selected specimens. Thereafter, $40 \%$ of this strength/strain were loaded on the concrete specimens placed in the experimental set. Table 4 shows the strains applied to the specimens. During strain loading, beating effect was avoided. Initially, a pre-loading of $10 \%$ of the strain was done, and then the strain was removed to ensure re-loading of permanent strain. The upper steel plate in the experimental set was tightened using blons so that the strain applied in the press machine could remain permanently on the experimental specimen. To ensure that the bolt pins in question were tightened with the same force, torque wrench was used. Considering that the required loads in the loading setups might decline in time, the bolt pins of the blons in the experimental set were tightened in 6 months. After the loading process, the experimental set with cylindrical concrete specimen on it was taken into the special controlledtemperature cabinet along with the shrinkage specimens.

On the days when creep measurements were made, further deformation measurements were made on the concrete shrinkage specimens kept in the same environment. Figure 2 shows strain deformations for the shrinkage experiments of concretes produced using 0,15 and $30 \%$ OSA-added cements.

The shrinkage and creep behaviors of substituted cements produced by adding 0,15 and $30 \%$ oil shale ash to Portland cement were examined for 12 months. The experiment was conducted in accordance with TS 3454 [16], and the measurement values are graphically presented in Figures 3 and 4. Measurements pertaining to various time intervals were indicated by dots in a semi-logarithmic axis, and thus information was obtained about the rate and general course of strain deformation, which is synthesis of creep and shrinkage.

Table 4. Compression strengths of cylindrical specimens

\begin{tabular}{|c|c|c|c|c|}
\hline Content of OSA, \% & Num. & $\begin{array}{c}\text { Max. strain, } \\
\mathrm{N} / \mathrm{mm}^{2}\end{array}$ & $\begin{array}{c}\text { Creep strain, } \\
(40 \%) \mathrm{N} / \mathrm{mm}^{2}\end{array}$ & $\begin{array}{c}\text { Number of } \\
\text { springs used }\end{array}$ \\
\hline 0 & 3 & 18.3 & 7.33 & 2 \\
$(100 \%$ OPC- Ref. Cem) & 3 & 16.6 & 6.64 & 1 \\
15 & 3 & 13.6 & 5.45 & 1 \\
\hline 30 &
\end{tabular}




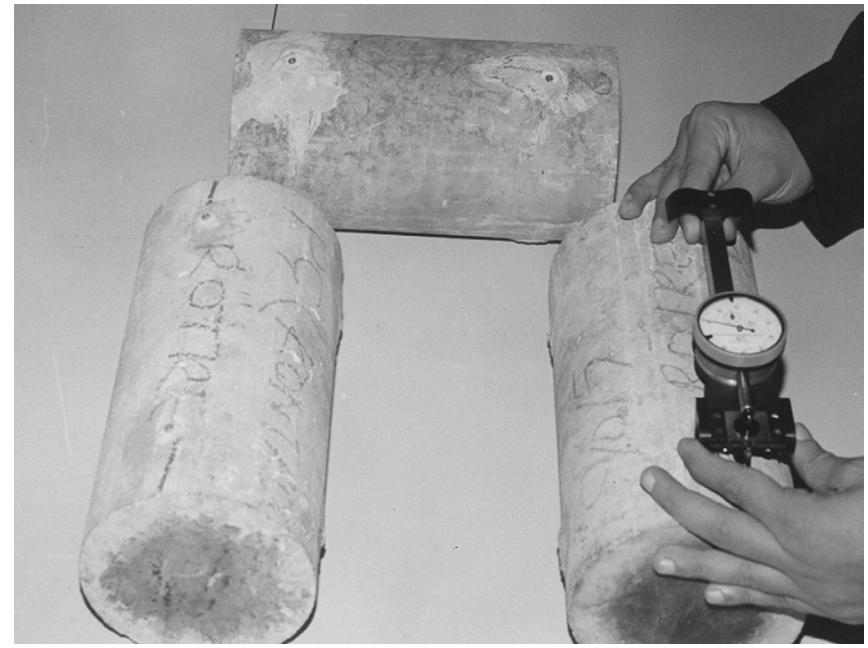

Fig. 2. Measurement of shrinkage deformations of specimens in the controlledtemperature cabinet.

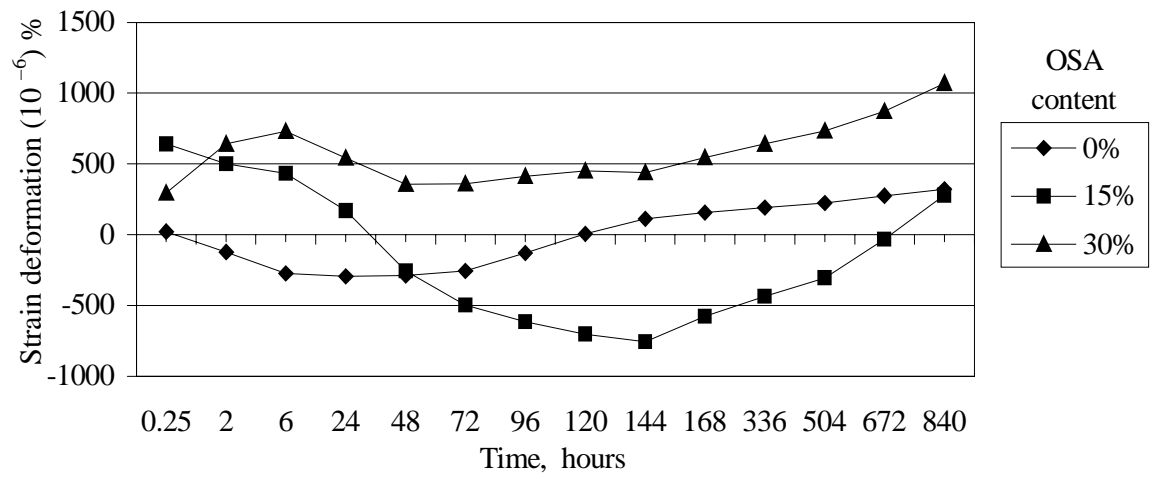

Fig. 3. 840-hour (one month) strain deformation of specimens.

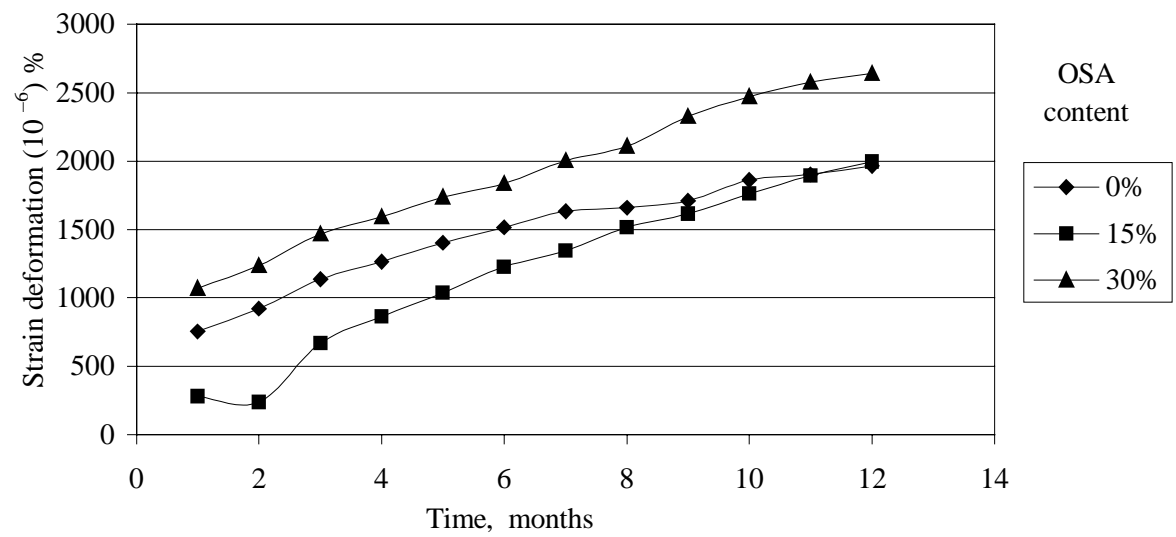

Fig. 4. 12-month strain deformation of specimens. 
Figure 3 shows one-month ( 840 hours) and Fig. 4 (depending on onemonth measurements) the total 12-month strain deformations. The curves in the figures do not follow a linear course. Yet, they follow a course increasing in time. The figures in question reveal that the creep course followed by $15 \%$ OSA-added concretes was partly similar to that of $0 \%$ OSA-added (OPC control) specimens. Nevertheless, the creep behavior of 30\% OSA-added specimens was much higher than that of the control specimen, which could be attributed to the remaining ash after the reaction in which 30\% OSA bonded free $\mathrm{Ca}(\mathrm{OH})_{2}$ in the cement. As a matter of fact, this is confirmed by the finding that the compression strength of $30 \%$ OSA-added specimens was higher than that of $15 \%$ OSA-added specimens, and that concretes with lower compression strength yielded a higher amount of creep.

Including sudden deformation amounts, creep and shrinkage deformations of the mixes in question whose curves are given were observed to be generally consistent with Neville's [6] examples. As stated in TS 3454, if the specimen surfaces had been paraffinized and a high-strength concrete grade had been chosen (lower high-strength creep and shrinkage values), somewhat lower creep and shrinkage values could have been obtained without any difference in the general course of deformations. In the long run, paraffinizing will prevent the water in the closed pores of the specimens from flowing out.

Consequently, this finding agrees with the condition that concrete specimens produced using $15 \%$ OSA-added cements would not have any deformations higher than $0.1 \%$ in six months and than $0.5 \%$ in three months [18]. It was concluded that concretes produced using these materials will not show any creep and shrinkage in an environment with an average temperature of $23{ }^{\circ} \mathrm{C}$ and a relative humidity of $54 \%$, and that no structure and surface deformations will take place due to creep and shrinkage. Therefore, it was understood that the highest amount of OSA to be added in OPC by weight is $15 \%$, and it could be used anywhere where OPC 32.5 is used.

\section{Conclusions}

As a consequence, the additive cements obtained by burning oil shale of Ankara-Beypazari Cayirhan region in Turkey at $700{ }^{\circ} \mathrm{C}$ and adding its ash to cement at the ratio of $15 \%$ by its mass comply with the additive cement standards and the previous studies on the subject. In such cements, grinding the ash together with clinker and gypsum will help to produce cement of higher quality.

\section{Acknowledgements}

The authors would like to thank Prof. Asım Yeğinobali, retired faculty member of Middle East Technical University (METU) and current 
Research and Development Director of the Turkish Cement Manufacturers' Association.

\section{REFERENCES}

1. Postacıoğlu, B. The Basics of Construction Material. - Matbaa Teknisyenleri Basımevi, Istanbul, 1988 [in Turkish].

2. Bazant, Z. P., Chern, J. C. Concrete creep at variable humidity: constitutive law and mechanism // Mater. Sruct. 1985. Vol. 18. P. 1-20.

3. Bazant, Z. P., Xi, Y. P. Drying creep of concrete: constitutive model and new experiments separating its mechanisms // Mater. Struct. 1994. Vol. 27, No. 165. P. 3-14.

4. Benboudjema, F., Meftah, F., Sellier, A., Torrenti, J. M., Heinfling, G. On the prediction of delayed strains for concrete subjected to drying and loading simultaneously // Proc. CONCREEP 6: Creep, Shrinkage and Durability Mechanics of Concrete and Other Quasi-Brittle Materials, Cambridge, USA, 2001. P. 245-250.

5. Mindess, S., Young, J. F. Concrete. - Prentice-Hall, Inc., New Jersey, 1981.

6. Neville, A. M. Properties of Concrete. - Pitman Publishing Ltd., London, 1983. P. 433-528.

7. Erdoğan, T. Concrete. - METU Press Publishing Company, Turkey, 2003. P. 741 [in Turkish].

8. Oymael, S. The Suitability of Oil Shale Ash as an Admixture in Cement and Concrete. - PhD Dissertation, Firat University, Elazig, 1995. P. 163 [in Turkish].

9. Oymael, S., Durmus, A. Effects of sulphates on elastic modulus of concrete samples made from blends of cement with oil shale ash // Oil Shale. 2006. Vol. 23, No. 2. P. $125-134$.

10. Oymael, $S$. The effect of sulphate on lenght change of concrete // Oil Shale. 2007. Vol. 24, No. 4. P. 561-571.

11. ASTM C 33. Standard Specification for Concrete Aggregates. - Annual Book of ASTM Standards, 1994.

12. ASTM C 109. Standard Test Method for Compressive Strength of Hydraulic Cement Mortars, 1993.

13. Turkish Standards, TS 25- Trass, Turkish Standards Institution, Ankara, 1975.

14. ASTM C 512. Standard Test Method for Creep of Concrete in Compression, 1992.

15. Turkish Standards, TS 3453 Test Method for Determining the Drying Shrinkage of Concrete Bloks, Turkish Standards Institution, Ankara, 1981.

16. Turkish Standards, TS 3454 Test Method for Determining the Creep of Concrete in Compression, Turkish Standards Institution, Ankara, 1981.

17. Turkish Standards, TS 206-1 Concrete Part I: Specification, Performance, Production and Confirmity, Turkish Standards Institution, 2002.

18. Cordon, W. A. Properties, Evaluation and Control of Engineering Materials. New York: McGraw-Hill, Inc., 1979.

Presented by J. Hilger

Received June 19, 2008 